\title{
Pengaruh Work Family Conflict dan Efikasi Diri terhadap \\ Pengembangan Karir Karyawan, Dimoderasi oleh Dukungan Organisasi pada Badan Pengelola Pajak dan Retribusi Daerah Kota Medan
}

\author{
Masyitha Agri Syafira \\ masitaagri09@gmail.com \\ Universitas Harapan Medan \\ Winda Ardiani \\ windaardiani.chan@gmail.com \\ Universitas Harapan Medan \\ Rizky Putra \\ rizkyputrase@gmail.com \\ Universitas Harapan Medan
}

\begin{abstract}
Abstrak
Penelitian ini bertujuan untuk mengetahui pengaruh work family conflict dan efikasi diri terhadap pengembangan karir karyawan Badan Pengelola Pajak dan Retribusi Daerah Kota Medan secara parsial. Untuk mengetahui apakah dukungan organisasi memoderasi pengaruh work family conflict dan efikasi diri terhadap pengembangan karir karyawan pada Badan Pengelola Pajak dan Retribusi Daerah Kota Medan. Jumlah populasi dalam penelitian ini adalah berjumlah 249 orang, dan dengan menggunakan purposive sampling karena ada kriteria inklusi diperoleh sampel sebesar 133 orang. Teknik analisis yang digunakan adalah regresi linier berganda dan MRA. Hasil penelitian menunjukkan bahwa work family conflict berpengaruh signifikan terhadap pengembangan karir karyawan pada Badan Pengelola Pajak dan Retribusi Daerah Kota Medan. Efikasi diri tidak berpengaruh terhadap pengembangan karir karyawan pada Badan Pengelola Pajak dan Retribusi Daerah Kota Medan. Dukungan organisasi tidak terbukti memoderasi pengaruh work family conflict terhadap pengembangan karir karyawan. Dukungan organisasi terbukti memoderasi efikasi diri terhadap pengembangan karir karyawan.
\end{abstract}

Kata kunci: work family conflict, efikasi diri, pengembangan karir karyawan, dukungan organisasi

\section{Pendahuluan}

Dewasa ini pengelolaan sumber daya manusia bagi sebuah organisasi tidak lagi sebatas hubungan antara majikan dan pekerja yang sifatnya satu arah, dalam arti para pekerja tidak memiliki hak-hak yang harus didengar dan diperhatikan oleh majikan. Hubungan yang berkembang dalam pengelolaan organisasi modern saat ini adalah hubungan dua arah yang seimbang. Perusahaan dalam hal ini sangat perlu untuk menjaga kesinambungan eksistensi dan pengabdian dari para karyawannya secara profesional (Muamarizal, Dr. Samsir, SE., M.Si Marzolina, SE, \& Faculty, 2015). Salah satu metode pengelolaan secara profesional adalah menyelenggarakan pengembangan karir. Pengembangan karir bagi karyawan merupakan sebuah bentuk pencapaian siklus perkembangan diri menjadi lebih baik secara ekonomi maupun status sosialnya. Keberlangsungan peningkatan karir bagi para karyawan menjadi kewajiban yang harus dipenuhi oleh perusahaan.

Menurut Panggabean (2014), bahwa pengembangan karir adalah semua usaha pribadi karyawan yang ditujukan untuk melaksanakan rencana karirnya melalui pendidikan, pelatihan, pencarian dan perolehan kerja serta pengalaman kerja. Menurut Nawawi (2011),, pengembangan karir adalah kegiatan manajemen sumber daya manusia pada dasarnya 
bertujuan untuk memperbaiki dan meningkatkan efektivitas pelaksanaan pekerjaan oleh para pekerja agar semakin mampu memberikan kontribusi terbaik dalam mewujudkan tujuan organisasi/perusahaan". Pelaksanaan pekerjaan yang semakin baik dan meningkat berpengaruh langsung pada peluang bagi seseorang pekerja untuk memperoleh posisi/jabatan yang diharapkan". Untuk dapat meningkatkan pengembangan karir maka work family conflict dan efikasi diri juga pelu diperhatikan sehingga karyawan dapat bekerja dengan baik dalam perusahaan. Menurut Greenhaus \& Beutell (1985), work family conflict (WFC) adalah salah satu dari bentuk interrole conflict yaitu tekanan atau ketidakseimbangan peran antara peran dipekerjaan dengan peran didalam keluarga. Jam kerja yang panjang dan beban kerja yang berat merupakan pertanda langsung akan terjadinya work family conflict (WFC), dikarenakan waktu dan upaya yang berlebihan dipakai untuk bekerja mengakibatkan kurangnya waktu dan energi yang bisa digunakan untuk melakukan aktivitas-aktivitas keluarga. Menurut Effendi (2014), konflik terjadi bila adanya beberapa tujuan yang ingin dicapai sekaligus dalam waktu yang sama, padahal itu tidak mungkin dapat terjadi. Biasanya merupakan kebutuhan yang sangat penting menurut kapasitas seseorang.

Selain work family conflict (WFC), pengembangan karir juga dipengaruhi oleh efikasi diri. Di mana efikasi diri menggambarkan efikasi diri sebagai penentu bagaimana orang merasa, berfikir, memotivasi diri, dan berperilaku. Bandura dalam Santrock (2017) mengatakan bahwa efikasi diri berpengaruh besar terhadap perilaku. Selain efikasi diri yang dapat mempengaruhi pengembangan karir karyawan, maka rekan kerja seperti dukungan organisasi juga diharapkan untuk dimiliki oleh karyawan. Efikasi diri merupakan salah satu aspek pengetahuan tentang diri atau self knowledge yang paling berpengaruh dalam kehidupan maanusia sehari-hari. Hal ini disebabkan efikasi diri yang dimiliki ikut mempengaruhi individu dalam menentukan tindakan yang akan dilakukan untuk mencapai suatu tujuan termasuk di dalamnya perkiraan berbagai kejadian yang akan dihadapi. Efikasi diri yakni keyakinan bahwa seseorang bisa menguasai situasi dan mendapatkan hasil positif. Marler, Fisher, \& Ke (2009) dalam penelitiannya menemukan bahwa pegawai dengan tingkat keyakinan yang tinggi akan dapat menyelesaikan pekerjaan yang diberikan kepadanya jika diikuti dengan dukungan yang tinggi dari organisasinya, dijelaskan bahwa pegawai tersebut akan lebih sensitif dalam bekerja, dan mau belajar menggunakan teknologi baru yang diterapkan oleh organisasinya yang akan berdampak pada kinerja yang maksimal. Dalam hal ini tingkat keyakinan individu pegawai (efikasi diri) yang melibatkan dukungan organisasional dapat menumbuhkan rasa kewajiban pegawai untuk mendukung tujuan organisasi yaitu mencapai kinerja yang maksimal.

Badan Pengelola Pajak dan Retribusi Daerah Kota Medan salah satu Institusi Pemerintahan yang bergerak dalam bidang retribusi dan pajak. Badan Pengelola Pajak dan Retribusi Kota Medan dengan tugas pokoknya mengelola bidang penerimaan atau pendapatan daerah. Oleh sebab itu karyawan merupakan salah satu unsur terpenting untuk tercapainya tujuan perusahaan dan diharapkan dapat menyelesaikan segala pekerjaan atau apapun tugas yang diberikan dengan baik dan menunjukkan kinerjanya dengan maksimal. Pengembangan karir wanita berbeda secara alamiah dibandingkan pria. Menurut Gillingan dalam Jati Waskito \& Ir. H. Irmawati (2012) menyatakan perbedaan tersebut terjadi baik dalam waktu dan cara bagaimana mereka mencoba memecahkan konflik dari tugas-tugas dan peran yang harus mereka alami pada masing-masing tahap pengembangan atau sepanjang siklus hidup mereka. Usaha pengembangan karir yang didambakan tiap karyawan wanita tergantung bagaimana karyawan tersebut menanggapi dan mengamatinya, atau dengan kata lain adalah bagaimana mereka mempersepsikannya. Artinya pengembangan karir yang diberikan perusahaan untuk memenuhi kebutuhan karyawan belum tentu karyawan mempersepsikannya demikian.

Badan Pengelola Pajak dan Retribusi Kota Medan juga memiliki program pengembangan karir yang baku bagi seluruh karyawannya. Namun demikian, pengembangan karir pegawai wanita sering terbentur dengan masalah keluarga di antaranya adalah ketegangan dan stress pada diri pegawai wanita yang bekerja, gangguan kesehatan baik ketika hamil atau datang bulan, dan ketidakharmonisan hubungan dengan anggota keluarga lain. Hal ini mengakibatkan 
berkurangnya komitmen pegawai wanita pada pekerjaan. Meskipun sama-sama bekerja, pegawai wanita lebih rentan mengalami work-family conflict dibandingkan dengan pegawai pria sehingga menghambat perkembangan karirnya. Selain itu, efikasi diri pegawai wanita umumnya lebih rendah untuk mengatasi hambatan yangada, karena mereka percaya bahwatindakan yang mereka lakukan tidak akan membawa pengaruh apapun. Hal ini juga berpengaruh terhadap pengembangan karirnya. Efikasi diri yang rendah dapat merusak motivasi, menurunkan aspirasi, mengganggu kemampuan kognitif, dan secara tidak langsung dapat mempengaruhi kesehatan fisik. Selain itu, adanya pegawai yang lebih sensitif dalam bekerja, dan kurang mau belajar menggunakan teknologi baru yang diterapkan oleh organisasinya yang akan berdampak pada kinerja yang maksimal sehingga karirnya menjadi mandek.

\section{Kajian Pustaka}

\subsection{Pengertian Pengembangan Karir Karyawan}

Menurut Handoko (2011), pengembangan karir adalah peningkatan-peningkatan pribadi yang dilakukan seseorang untuk mencapai suatu rencana karir. Panggabean (2014), menyatakan bahwa pengembangan karir adalah semua usaha pribadi karyawan yang ditujukan untuk melaksanakan rencana karirnya melalui pendidikan, pelatihan, pencarian dan perolehan kerja serta pengalaman kerja. Sedangkan menurut Rivai (2015), pengembangan karir adalah proses peningkatan kemampuan kerja individu yang dicapai dalam rangka mencapai karir yang diinginkan.

\subsection{Indikator Pengembangan Karir Karyawan}

Menurut Handoko (2011), indikator pengembangan karir adalah :

1) Pengembangan karir karyawan

2) Exposure

3) Kesetiaan Organisasional

4) Mentor dan Sponsor

5) Kesempatan-Kesempatan untuk Tumbuh

6) Dukungan Manajemen

\subsection{Pengertian Work Family Conflict (WFC)}

Menurut Triaryati (2003), work family conflict (WFC) merupakan suatu bentuk konflik peran di mana tuntutan peran dari pekerjaan dan keluarga secara mutual tidak dapat disejajarkan dalam beberapa hal. Menurut Bandura (2016), work family conflict (WFC) didefinisikan sebagai bentuk konflik antar peran di mana tekanan dari peran pekerjaan dan keluarga saling bertentangan. Ketidakcocokan tersebut ditunjukkan dengan kenyataan partisipasi dalam peran pekerjaan dibuat lebih sulit berdasarkan partisipasi dalam peran keluarga dan sebaliknya.

\subsection{Indikator Work Family Conflict (WFC)}

Frone, Russell, \& Cooper (1992) mengemukakan tiga indikator yang mempengaruhi work family conflict (WFC), yaitu :

1) Dari dalam diri individu

Meliputi ciri demografis (jenis kelamin, usia, status keluarga, dan lain-lain), kepribadian, ketelitian dan ketabahan

2) Peran keluarga

Meliputi alokasi waktu untuk pekerjaan dan keluarga, stressor dari keluarga, jenis kerjaan terhadap stressor keluarga, mempunyai anak dan dukungan organisasi.

3) Peran pekerjaan

Meliputi alokasi waktu untuk perkerjaan, konflik peran kerja, ambiguitas peran kerja, stres kerja, karakteristik pekerjaan, dukungan organisasi dari atasan dan rekan kerja serta karakteristik tempat kerja. 


\subsection{Pengertian Efikasi Diri}

Bandura (2016) menggambarkan efikasi diri sebagai penentu bagaimana orang merasa, berfikir, memotivasi diri, dan berperilaku. Efikasi diri merupakan salah satu aspek pengetahuan tentang diri atau self knowwledge yang palingber pengaruh dalam kehidupan maanusia seharihari. Hal ini disebabkan efikasi diri yang dimiliki ikut mempengaruhi individu dalam menentukan tindakan yang akan dilakukan untuk mencapai suatu tujuan termasuk di dalamnya perkiraan berbagai kejadian yang akan dihadapi. Efikasi diri yakni keyakinan bahwa seseorang bisa menguasai situasi dan mendapatkan hasil positif. Bandura dalam Santrock (2017) mengatakan bahwa efikasi diri berpengaruh besar terhadap perilaku.

\subsection{Indikator Efikasi Diri}

Menurut Bandura (2016), efikasi diri pada diri tiap individu akan berbeda antara satu individu dengan yang lainnya berdasarkan tiga dimensi, yaitu:

1) Tingkat (Level)

Dimensi ini berkaitan dengan derajat kesulitan tugas ketika individu merasa mampu untuk melakukannya. Apabila individu dihadapkan pada tugas-tugas yang disusun menurut tingkat kesulitannya, maka efikasi diri individu mungkin akan terbatas pada tugas-tugas yang mudah, sedang, atau bahkan meliputi tugas-tugas yang paling sulit, sesuai dengan batas kemampuan yang dirasakan untuk memenuhi tuntutan perilaku yang dibutuhkan pada masing-masing tingkat.

2) Kekuatan (Strength)

Dimensi ini berkaitan dengan tingkat kekuatan dari keyakinan atau pengharapan individu mengenai kemampuannya. Pengharapan yang lemah mudah digoyahkan oleh pengalaman-pengalaman yang tidak mendukung. Sebaliknya, pengharapan yang mantap mendorong individu tetap bertahan dalam usahanya. Meskipun mungkin ditemukan pengalaman yang kurang menunjang.

3) Generalisasi (Geneality)

Dimensi ini berkaitan dengan luas bidang tingkah laku yang mana individu merasa yakin akan kemampuannya. Individu dapat merasa yakin terhadap kemampuan dirinya. Apakah terbatas pada suatu aktivitas dan situasi tertentu atau pada serangkaian aktivitas dan situasi yang bervariasi.

\section{7. $\quad$ Pengertian Dukungan Organisasi}

Marler et al. (2009) dalam penelitiannya menemukan bahwa pegawai dengan tingkat keyakinan yang tinggi akan dapat menyelesaikan pekerjaan yang diberikan kepadanya jika diikuti dengan dukungan yang tinggi dari organisasinya. Dijelaskan bahwa pegawai tersebut akan lebih sensitif dalam bekerja, dan mau belajar menggunakan teknologi baru yang diterapkan oleh organisasinya yang akan berdampak pada kinerja yang maksimal. Dalam hal ini tingkat keyakinan individu pegawai (efikasi diri) yang melibatkan dukungan organisasional dapat menumbuhkan rasa kewajiban pegawai untuk mendukung tujuan organisasi yaitu mencapai kinerja yang maksimal.

\subsection{Indikator Dukungan Organisasi}

Sebuah meta-analisis yang dilakukan oleh Rhoades \& Eisenberger (2002) mengindikasikan bahwa 3 kategori utama dari perlakuan yang dipersepsikan oleh karyawan memiliki hubungan dengan persepsi dukungan organisasi, yaitu :

1) Keadilan

2) Dukungan atasan

3) Penghargaan organisasi dan kondisi pekerjaan 


\subsection{Hubungan Work Family Conflict Terhadap Pengembangan Karir Karyawan}

Kinicki (2014) mengungkapkan bahwa munculnya work family conflict (WFC) disebabkan adanya benturan antara value similarity dan value congruence. Value similarity diartikan sebagai tingkat kesepakatan diantara anggota keluarga mengenai nilai-nilai yang ada dalam keluarga tersebut, sedangkan value congruence merupakan sejumlah nilai-niai yang disepakati antara karyawan dengan organisasi. Work family conflict (WFC) tersebut yang akan mempengaruhi tingkat kepuasan hidup individu baik sebagai karyawan maupun sebagai anggota keluarga. Benturan yang terjadi yang bersifat positif akan dapat membantu karyawan dalam mengembangkan karirnya di dalam perusahaan serta dapat meningkatkan kinerjanya dalam perusahaan tersebut. Jackson \& Yohanes Arianto (2017) menyatakan bahwa work family conflict (WFC) berpengaruh positif dan signifikan terhadap pengembangan karir. Begitu juga dengan Afrilia \& Utami (2018) yang menyatakan bahwa pengaruh variabel Work Family Conflict terhadap pengembangan karir karyawan signifikan. Berdasarkan uraian di atas, maka hipotesis penelitiannya adalah :

$\mathbf{H}_{\mathbf{1}}$ : Work Family Conflict berpengaruh signifikan terhadap pengembangan karir karyawan pada Badan Pengelola Pajak dan Retribusi Daerah Kota Medan.

\subsection{Hubungan Efikasi Diri Terhadap Pengembangan Karir Karyawan}

Konsep efikasi diri sebenarnya adalah inti dari teori social cognitive yang dikemukakan oleh Bandura yang menekankan peran belajar observasional, pengalaman social, dan determinisme timbal balik dalam pengembangan kepribadian. Menurut Bandura (2016) efikasi diri adalah keyakinan seseorang dalam kemampuannya untuk melakukan suatu bentuk kontrol terhadap fungsi orang itu sendiri dan kejadian dalam lingkungan. Dengan tingginya tingkat keyakinan yang dimiliki oleh karyawan akan berpengaruh terhadap pengembangan karir karyawan yang bersangkutan dan berdampak terhadap tingginya dukungan organisasi terhadap diri karyawan itu sendiri. A.A. Ayu Ngr. Dinni Saraswathi., Dewi, \& Piartini (2017) dan Nurtjahjanti, Endah Mujiasih, Prihatsanti, Prasetyo, \& Ratnaningsih (2012) menyatakan bahwa efikasi diri berpengaruh positif dan signifikan terhadap pengembangan karir karyawan. Berdasarkan uraian di atas, maka hipotesis penelitiannya adalah :

$\mathbf{H}_{2}$ : Efikasi diri berpengaruh signifikan terhadap pengembangan karir karyawan pada Badan Pengelola Pajak dan Retribusi Daerah Kota Medan.

\subsection{Dukungan Organisasi Memoderasi Pengaruh Work Family Conflict Terhadap Pengembangan Karir Karyawan}

Marler et al. (2009) dalam penelitiannya menemukan bahwa pegawai dengan tingkat keyakinan yang tinggi akan dapat menyelesaikan pekerjaan yang diberikan kepadanya jika diikuti dengan dukungan yang tinggi dari organisasinya, dijelaskan bahwa pegawai tersebut akan lebih sensitif dalam bekerja, dan mau belajar menggunakan teknologi baru yang diterapkan oleh organisasinya yang akan berdampak pada kinerja yang maksimal. A.A. Ayu Ngr. Dinni Saraswathi. et al. (2017) menyatakan work family conflict (WFC) berpengaruh positif pada pengembangan karir pegawai. Dukungan organisasional memberi efek moderasi terhadap pengembangan karir, yang artinya dukungan organisasional mampu memperkuat pengaruh work family conflict (WFC) terhadap pengembangan karir pegawai. Berdasarkan uraian di atas, maka hipotesis penelitiannya adalah :

$\mathbf{H}_{3}$ : Dukungan organisasi memoderasi pengaruh work family conflict (WFC) terhadap pengembangan karir karyawan pada Badan Pengelola Pajak dan Retribusi Daerah Kota Medan. 


\subsection{Dukungan Organisasi Memoderasi Pengaruh Efikasi Diri Terhadap Pengembangan Karir Karyawan}

Hukum timbal balik (norm of reciprocity) menyatakan bahwa individu yang diperlakukan dengan baik oleh pihak lain akan merasa berkewajiban untuk membalasnya dengan perlakuan baik pula (Blau, 2017). Settoon, Bennett, \& Liden (1996) menyatakan bahwa dukungan organisasional yang dipersepsikan level tinggi akan menciptakan kewajiban bagi individu untuk memberikan timbal baliknya. Afrilia \& Utami (2018) menyatakan efikasi diri berpengaruh positif pada pengembangan karir pegawai. Efek moderasi dukungan organisasional terhadap pengembangan karir juga ditemukan signifikan yang artinya dukungan organisasional mampu memoderasi (memperkuat) pengaruh efikasi diri terhadap pengembangan karir pegawai.Berdasarkan uraian di atas, maka hipotesis penelitiannya adalah :

$\mathbf{H}_{4}$ : Dukungan organisasi memoderasi pengaruh efikasi diri terhadap pengembangan karir karyawan pada Badan Pengelola Pajak dan Retribusi Daerah Kota Medan.

\section{Metode Penelitian}

\subsection{Jenis Penelitian}

Penelitian ini menggunakan kuantitatif yang merupakan penelitian yang bertujuan untuk mengetahui pengaruh dua variabel $X$ atau lebih terhadap variabel Y (Sugiyono, 2012). Dalam penelitian ini bertujuan mengetahui pengaruh work family conflict (WFC) dan efikasi diri terhadap pengembangan karir karyawan dan untuk mengetahui apakah dukungan organisasi memperkuat atau memperlemah hubungan antara work family conflict (WFC) dan efikasi diri dengan pengembangan karir karyawan pada Badan Pengelola Pajak dan Retribusi Daerah Kota Medan.

\subsection{Teknik Analisis Data Penelitian}

3.2.1. Persamaan Regresi Linier Berganda

Persamaannya adalah sebagai berikut :

$\begin{array}{lll}\mathrm{Y} & = & \mathrm{a}+\mathrm{b}_{1} \mathrm{X}_{1}+\mathrm{b}_{2} \mathrm{X}_{2}+ \\ \mathrm{Y} & = & \text { Pengembangan karir karyawan } \\ \mathrm{a} & = & \text { nilai } \mathrm{y}, \text { apabila } \mathrm{X}_{1}=\mathrm{X}_{2} \\ \mathrm{~b}_{1}, \mathrm{~b}_{2} & = & \text { koefisien regresi berganda } \\ \mathrm{X}_{1} & = & \text { Work family conflict } \\ \mathrm{X}_{2} & = & \text { Efikasi diri } \\ & = & \text { Standard Error }\end{array}$

Persamaan ini digunakan untuk menguji hipotesis 1 dan hipotesis 2.

\subsubsection{Moderated Regression Analysis (MRA)}

MRA I Hipotesis 3

1) Persamaan 2

$$
\mathrm{Z}=\mathrm{a}+\mathrm{b}_{3} \mathrm{X}_{1}+\mathrm{e} 1
$$

2) Persamaan 3

$\mathrm{e}_{\text {absolute } 1}=\mathrm{a}-\mathrm{b}_{4} \mathrm{Y}$

MRA I Hipotesis 4

1) Persamaan 2

$$
\mathrm{Z}=\mathrm{a}+\mathrm{b}_{5} \mathrm{X}_{2}+\mathrm{e} 2
$$

2) Persamaan 3

$\mathrm{e}_{\text {absolute2 }}=\mathrm{a}-\mathrm{b}_{6} \mathrm{Y}$

Persamaan ini digunakan untuk menguji hipotesis 3 dan hipotesis 4 . 


\section{Analisis Data dan Pembahasan}

4.1. Analisis Data

4.1.1. Uji Regresi Linier Berganda

Tabel 1. Koefisien Regresi Berganda

\begin{tabular}{|c|c|c|c|c|c|}
\hline \multirow[t]{2}{*}{ Model } & \multicolumn{2}{|c|}{$\begin{array}{l}\text { Unstandardized } \\
\text { Coefisients }\end{array}$} & \multirow{2}{*}{\begin{tabular}{|c|} 
Standardized Coefisients \\
Beta
\end{tabular}} & \multirow[t]{2}{*}{ t } & \multirow[t]{2}{*}{ Sig } \\
\hline & $\bar{B}$ & Std. Error & & & \\
\hline (Constant) & 23.539 & 5.214 & & 4.514 & .000 \\
\hline Work family conflict & .345 & .163 & .182 & 2.132 & .036 \\
\hline Efikasi diri & .176 & .128 & .118 & .1 .380 & .170 \\
\hline
\end{tabular}

Sumber : data diolah

$$
Y=23.539+0.345 X_{1}+0.176 X_{2}
$$

4.1.2. Uji F

Tabel 2. Hasil Uji F

\begin{tabular}{|l|r|r|r|c|r|}
\hline Model & Sum of Squares & d & Mean Square & F & Sig \\
\hline Regression & 285.571 & 2 & 142.786 & 3.123 & 047 \\
Residual & 5943.135 & 130 & 45.716 & & \\
\hline Total & 6228.707 & 132 & & & \\
\hline
\end{tabular}

Sumber : data diolah

Dari hasil uji $F$ di atas, dapat bahwa $F_{\text {hitung }}>F_{\text {tabel }}(3,123>3,06)$ atau sig $F<5 \%$ $(0,047<0,05)$. Artinya model ini telah fit dan dapat digunakan dalam penelitian ini.

\subsubsection{Uji t}

Pengujian hipotesis 1 dan 2 uji regresi dapat dilihat pada Tabel 3.

\begin{tabular}{|c|c|c|c|c|c|}
\hline \multicolumn{6}{|c|}{ Tabel 3. Hasil Uji t } \\
\hline \multirow[t]{2}{*}{ Model } & \multicolumn{2}{|c|}{$\begin{array}{l}\text { Unstandardized } \\
\text { Coefisients }\end{array}$} & \multirow{2}{*}{\begin{tabular}{|c|} 
Standardized Coefisients \\
Beta
\end{tabular}} & \multirow[t]{2}{*}{$\mathbf{t}$} & \multirow[t]{2}{*}{ Sig } \\
\hline & $\bar{B}$ & Std. Error & & & \\
\hline (Constant) & 23.539 & 5.214 & & 4.514 & .000 \\
\hline Work family conflict & .345 & .163 & .182 & 2.132 & .036 \\
\hline Efikasi diri & .176 & .128 & .118 & .1 .380 & .170 \\
\hline
\end{tabular}

\section{Sumber : data diolah}

Nilai t-hitung untuk $\mathrm{X}_{1}$, > t-tabel $(2,132>1.978)$ dan nilai Sig. $(0,036<0,05)$, maka work family conflict berpengaruh positif dan signifikan terhadap pengembangan karir karyawan.Untuk $\mathrm{X}_{2}$, nilai t-hitung < t-tabel $(1.380<1.978)$ dan nilai Sig. $(0,170>0,05)$, dengan demikian efikasi diri tidakberpengaruh terhadap pengembangan karir karyawan.

\subsubsection{Uji Determinasi}

Tabel 4. Koefisien Determinasi

\begin{tabular}{|c|c|c|c|c|}
\hline Model & R & R Square & Adjusted R Square & Std. Error of the Estimate \\
\hline 1 & .214 & .046 & .031 & 6.76139 \\
\hline
\end{tabular}

Sumber : data diolah

Variabel pengembangan karir karyawan (Y) dipengaruhi oleh variabel $\mathrm{X}_{1}$ (work family conflict) dan variabel $\mathrm{X}_{2}$ (efikasi diri) secara serentak sebesar $4.6 \%$ dan sisanya sebesar $95.4 \%$ ditentukan oleh variabel lain yang tidak diteliti dalam penelitian ini. 
Moderated Regression Analysis

MRA 1 (Hipotesis 3)

\section{Persamaan Model 2}

$$
Z=\mathbf{a}+\mathbf{b}_{3} \mathbf{X}_{1}+\mathbf{e}_{1}
$$

\subsubsection{Uji Normalitas}

Tabel 5. Hasil Uji Kolmogorov-Smirnov MRA 1

\begin{tabular}{|l|l|r|}
\hline \multicolumn{2}{|c|}{ One-Sample Kolmogorov-Smirnov Test } \\
\hline N & Unstandardized Residual \\
\hline Normal Parameters ${ }^{\text {a,b }}$ & Mean &, 0000000 \\
\hline & Std. Deviation & 4,32268009 \\
\hline Most Extreme Differences & Absolute &, 110 \\
\hline & Positive &, 081 \\
\hline & Negative &,- 110 \\
\hline \multicolumn{2}{|l|}{} & 1,270 \\
\hline Kolmogorov-Smirnov Z &, 080 \\
\hline Asymp. Sig. (2-tailed) & \\
\hline a. Test distribution is Normal. \\
\hline b. Calculated from data.
\end{tabular}

Sumber : Data diolah

Tabel 6. Hasil Uji Regresi I

Coefficients $^{\mathrm{a}}$

\begin{tabular}{|l|r|c|c|c|c|}
\hline \multicolumn{1}{|c|}{ Model } & \multicolumn{2}{|c|}{ Unstandardized Coefficients } & Standardized Coefficients & $\mathrm{t}$ & Sig. \\
\hline & $\mathrm{B}$ & Std. Error & Beta & & \\
\hline \multicolumn{1}{|c|}{ Constant) } & 11,628 & 2,623 & & 4,434 & 000 \\
\hline $\begin{array}{l}\text { Work Family } \\
\text { Conflict }\end{array}$ &, 480 &, 104 & 373 & 4,599 & 000 \\
\hline
\end{tabular}

Sumber : Data diolah

Berdasarkan Tabel 6, menunjukkan nilai koefisien B sebesar $=11,628+0,480$.

1) Konstanta (a) = 11.628 menunjukkan harga konstan, dimana jika nilai variabel independen tetap, maka dukungan organisasibertambah sebesar 11.628.

2) Koefisien $\mathrm{X}_{1}\left(\mathrm{~b}_{1}\right)=0.480$, menunjukkan bahwa variabel work family conflict $\left(\mathrm{X}_{1}\right)$ berpengaruh positif dan signifikan terhadap dukungan organisasi (Z) dan akan menambah dukungan organisasisebesar 0.480 .

\subsubsection{Uji Heteroskedastisitas}

Tabel 7. Hasil Uji Glejser MRA 1

\begin{tabular}{|l|l|c|c|c|c|c|}
\hline \multicolumn{7}{|c|}{ Coefficients $^{\text {a }}$} \\
\hline \multicolumn{2}{|l|}{ Model } & Unstandardized Coefficients & Standardized Coefficients & t & Sig. \\
\hline 1 & B & Std. Error & Beta & & \\
\hline 1 & (Constant) & 5,171 & 1,554 & & 3,326 &, 001 \\
\hline & $\begin{array}{l}\text { Work Family } \\
\text { Conflict }\end{array}$ &,- 069 &, 062 &,- 097 & $-1,112$ &, 268 \\
\hline
\end{tabular}

Sumber : Data diolah 
Pada Tabel 7 menunjukkan bahwa nilai signifikansi variabel independen lebih dari 0.05 $(0,268>0,05)$, dengan demikian dapat disimpulkan bahwa tidak ada indikasi heteroskedastisitas pada model regresi.

\section{Persamaan Model 3}

$\boldsymbol{e}_{\text {absolute }}=\mathbf{a}-\mathbf{b}_{4} \mathbf{Y}$

Tabel 8. Hasil Uji MRA I

\begin{tabular}{|l|l|r|r|r|r|r|}
\hline \multicolumn{9}{|c|}{ Coefficients $^{\mathrm{a}}$} \\
\hline \multicolumn{2}{|l|}{ Model } & \multicolumn{1}{|c|}{$\begin{array}{c}\text { Unstandardized } \\
\text { Coefficients }\end{array}$} & $\begin{array}{c}\text { Standardized } \\
\text { Coefficients }\end{array}$ & $\mathrm{t}$ & Sig. \\
\hline & $\mathrm{B}$ & Std. Error & Beta & & \\
\hline 1 & (Constant) & 4,956 & 1,207 & & 4,107 &, 000 \\
\hline & Pengembangan Karir Karyawan &,- 041 &, 033 &,- 110 & $-1,262$ &, 209 \\
\hline \multicolumn{2}{|l|}{ a. Dependent Variable: Eabsolute1 } \\
\hline
\end{tabular}

\section{Sumber : Data diolah}

Berdasarkan Tabel 8, menunjukkan nilai koefisien B sebesar $=0,041$, dimana nilai konstanta ke arah positif dengan nilai signifikansi lebih besar dari 0,05 yakni 0,209>0,05. Dengan demikian dapat disimpulkan bahwa $\mathrm{H}_{3}$ ditolak dan $\mathrm{H}_{0}$ diterima yaitu dukungan organisasi tidak memoderasi hubungan antara work family conflict (WFC) terhadap pengembangan karir karyawan pada Badan Pengelola Pajak dan Retribusi Daerah Kota Medan.

\section{MRA II (Hipotesis 4) \\ Persamaan Model 4 \\ $\mathbf{Z}=\mathbf{a}+\mathbf{b}_{4} \mathbf{X}_{2}+\mathbf{e}_{2}$}

\subsubsection{Uji Normalitas}

Tabel 9. Hasil Uji Kolmogorov-Smirnov MRA II

\begin{tabular}{|l|l|r|}
\hline \multicolumn{2}{|c|}{ One-Sample Kolmogorov-Smirnov Test } \\
\hline $\mathrm{N}$ & Unstandardized Residual \\
\hline Normal Parameters ${ }^{\mathrm{a}, \mathrm{b}}$ & Mean & 133 \\
\hline & Std. Deviation &, 0000000 \\
\hline $\begin{array}{l}\text { Most Extreme } \\
\text { Differences }\end{array}$ & Absolute & 4,61225558 \\
\hline & Positive &, 117 \\
\hline \multicolumn{2}{|l|}{} &, 074 \\
\hline Kolmogorov-Smirnov Z & Negative &,- 117 \\
\hline Asymp. Sig. (2-tailed) & 1,348 \\
\hline
\end{tabular}

Sumber : Data diolah

Dari Tabel 9 di atas terlihat bahwa nilai signifikansi (Asyimp.Sig 2-tailed) sebesar 1.348. Karena signifikansi lebih besar dari $0.05(0.053>0.05)$, maka nilai residual tersebut telah normal. 
Tabel 10. Hasil Uji Regresi II

\begin{tabular}{|l|l|r|r|r|c|c|}
\hline \multicolumn{7}{|c|}{ Coefficients $^{\mathbf{a}}$} \\
\hline \multicolumn{2}{|l|}{ Model } & Unstandardized Coefficients & Standardized Coefficients & t & Sig. \\
\hline \multicolumn{2}{|r|}{} & B & Std. Error & Beta & & \\
\hline 1 & (Constant) & 20,092 & 2,172 & & 9,249 &, 000 \\
\hline & Efikasi Diri &, 142 &, 087 &, 141 & 1,626 &, 106 \\
\hline \multicolumn{2}{|l|}{ a. Dependent Variable: Dukungan Organisasi } \\
\hline
\end{tabular}

Sumber : Data diolah

Berdasarkan Tabel 10, menunjukkan nilai koefisien B sebesar $=20,092+0,142 .$.

1) Konstanta (a) $=20.092$ menunjukkan harga konstan, dimana jika nilai variabel independen tetap, maka dukungan organisasibertambah sebesar 11.628.

2) Koefisien $X_{2}\left(b_{2}\right)=0.142$, menunjukkan bahwa variabel efikasi diri $\left(X_{2}\right)$ berpengaruh positif dan signifikan terhadap dukungan organisasi (Z) dan akan menambah dukungan organisasisebesar 0.142 .

\subsubsection{Uji Heteroskedastisitas}

Tabel 11. Hasil Uji Glejser MRA 2

\begin{tabular}{|l|l|r|r|r|r|r|}
\hline \multicolumn{7}{|c|}{ Coefficients $^{\text {a }}$} \\
\hline \multicolumn{2}{|l|}{ Model } & Unstandardized Coefficients & Standardized Coefficients & t & Sig. \\
\hline \multicolumn{2}{|l|}{} & B & Std. Error & Beta & & \\
\hline 1 & (Constant) & 5,475 & 1,224 & & 4,472 &, 000 \\
\hline & Efikasi Diri &,- 069 &, 049 &,- 122 & $-1,407$ &, 162 \\
\hline \multicolumn{2}{|l|}{ a. Dependent Variable: Eabsolute2 } \\
\hline
\end{tabular}

Sumber : data diolah

Pada Tabel 11 menunjukkan bahwa nilai signifikansi variabel independen lebih dari 0.05 $(0,162>0,05)$, dengan demikian dapat disimpulkan bahwa tidak ada indikasi heteroskedastisitas pada model regresi.

\section{Persamaan Model 5}

$e_{\text {absolute }}=\mathbf{a}-\mathbf{b}_{5} \mathbf{Y}$

Tabel 12. Hasil Uji MRA II

\begin{tabular}{|l|l|r|r|r|r|r|}
\hline \multicolumn{7}{|c|}{ Coefficients $^{\mathbf{a}}$} \\
\hline \multicolumn{2}{|l|}{ Model } & \multicolumn{2}{|c|}{$\begin{array}{c}\text { Unstandardized } \\
\text { Coefficients }\end{array}$} & $\begin{array}{c}\text { Standardized } \\
\text { Coefficients }\end{array}$ & $\mathrm{t}$ & Sig. \\
\hline & $\mathrm{B}$ & Std. Error & Beta & & \\
\hline 1 & (Constant) & 7,441 & 1,191 & & 6,246 &, 000 \\
\hline & Pengembangan Karir Karyawan &,- 100 &, 032 &,- 263 & $-3,125$ &, 002 \\
\hline \multicolumn{2}{|l|}{ a. Dependent Variable: Eabsolute2 } \\
\hline
\end{tabular}

Sumber : data diolah

Berdasarkan Tabel 12, menunjukkan nilai koefisien $\mathrm{B}$ sebesar $=0,100$, dimana nilai konstanta ke arah positif dengan nilai signifikansi lebih kecil dari 0,05 yakni 0,002 < 0,05. Dengan demikian dapat disimpulkan bahwa $\mathrm{H}_{4}$ diterima dan $\mathrm{H}_{0}$ ditolak yaitu dukungan organisasi memoderasi hubungan antara efikasi diri terhadap pengembangan karir karyawan pada Badan Pengelola Pajak dan Retribusi Daerah Kota Medan. 


\subsection{Pembahasan}

\subsubsection{Pengaruh Work Family Conflict Terhadap Pengembangan Karir Karyawan}

Berdasarkan hasil pengujian statistik diperoleh hasil bahwa work family conflict (WFC) berpengaruh signifikan terhadap semangat kerja karyawan pada Badan Pengelola Pajak dan Retribusi Daerah Kota Medan. Kinicki (2014) mengungkapkan bahwa munculnya work family conflict (WFC) disebabkan adanya benturan antara value similarity dan value congruence. Value similarity diartikan sebagai tingkat kesepakatan diantara anggota keluarga mengenai nilai-nilai yang ada dalam keluarga tersebut, sedangkan value congruence merupakan sejumlah nilai-niai yang disepakati antara karyawan dengan organisasi. Work family conflict (WFC) tersebut yang akan mempengaruhi tingkat kepuasan hidup individu baik sebagai karyawan maupun sebagai anggota keluarga. Benturan yang terjadi yang bersifat positif akan dapat membantu karyawan dalam mengembangkan karirnya di dalam perusahaan serta dapat meningkatkan kinerjanya dalam perusahaan tersebut.Hasil penelitian ini sejalan dengan hasil penelitian yang dilakukan oleh Jackson \& Yohanes Arianto (2017) dan Afrilia \& Utami (2018) yang menyatakan bahwa variabel work family conflict (WFC) berpengaruh signifikan terhadap pengembangan karir karyawan. Begitu juga dengan penelitian yang dilakukan oleh Candra \& Ardana (2016) yang menyatakan bahwa work family conflict (WFC) memperkuat hubungan antara pendidikan dan pelatihan terhadap pengembangan karir

\subsubsection{Pengaruh Efikasi Diri Terhadap Pengembangan Karir Karyawan}

Berdasarkan hasil pengujian statistik diperoleh hasil bahwa efikasi diri tidak berpengaruh terhadap pengembangan karir karyawan pada Badan Pengelola Pajak dan Retribusi Daerah Kota Medan. Konsep efikasi diri sebenarnya adalah inti dari teori social cognitive yang dikemukakan oleh Bandura yang menekankan peran belajar observasional, pengalaman social, dan determinisme timbal balik dalam pengembangan kepribadian. Menurut Bandura (2016), efikasi diri adalah keyakinan seseorang dalam kemampuannya untuk melakukan suatu bentuk kontrol terhadap fungsi orang itu sendiri dan kejadian dalam lingkungan. Dengan tingginya tingkat keyakinan yang dimiliki oleh karyawan akan berpengaruh terhadap pengembangan karir karyawan yang bersangkutan dan berdampak terhadap tingginya dukungan organisasi terhadap diri karyawan itu sendiri.Hasil penelitian ini tidak sejalan dengan hasil penelitian yang dilakukan oleh A.A. Ayu Ngr. Dinni Saraswathi. et al. (2017) dan Nurtjahjanti et al. (2012) yang menyatakan bahwa efikasi diri berpengaruh positif dan signifikan terhadap pengembangan karir karyawan.

\subsubsection{Dukungan Organisasi Memoderasi Pengaruh Work Family Conflict Terhadap Pengembangan Karir Karyawan}

Berdasarkan hasil pengujian statistik diperoleh hasil bahwa dukungan organisasi tidak memoderasi hubungan work family conflict (WFC) antara terhadap pengembangan karir karyawan pada Badan Pengelola Pajak dan Retribusi Daerah Kota Medan. Marler et al. (2009) dalam penelitiannya menemukan bahwa pegawai dengan tingkat keyakinan yang tinggi akan dapat menyelesaikan pekerjaan yang diberikan kepadanya jika diikuti dengan dukungan yang tinggi dari organisasinya, dijelaskan bahwa pegawai tersebut akan lebih sensitif dalam bekerja, dan mau belajar menggunakan teknologi baru yang diterapkan oleh organisasinya yang akan berdampak pada kinerja yang maksimal. Dalam hal ini tingkat keyakinan individu pegawai (efikasi diri) yang melibatkan dukungan organisasional dapat menumbuhkan rasa kewajiban pegawai untuk mendukung tujuan organisasi yaitu mencapai kinerja yang maksimal. Hasil penelitian ini tidak sejalan dengan hasil penelitian yang dilakukan oleh A.A. Ayu Ngr. Dinni Saraswathi. et al. (2017) yang menyatakan bahwa work family conflict (WFC) berpengaruh positif dan signifikan terhadap pengembangan karir karyawan yang diperkuat oleh dukungan organisasi. 


\subsubsection{Dukungan Organisasi Memoderasi Pengaruh Efikasi Diri Terhadap Pengembangan Karir Karyawan}

Berdasarkan hasil pengujian statistik diperoleh hasil bahwa dukungan organisasi memoderasi hubungan efikasi diri antara terhadap pengembangan karir karyawan pada Badan Pengelola Pajak dan Retribusi Daerah Kota Medan.Hukum timbal balik (norm of reciprocity) menyatakan bahwa individu yang diperlakukan dengan baik oleh pihak lain akan merasa berkewajiban untuk membalasnya dengan perlakuan baik pula (Blau, 2017). Settoon et al., (1996) menyatakan bahwa dukungan organisasional yang dipersepsikan level tinggi akan menciptakan kewajiban bagi individu untuk memberikan timbal baliknya. Hasil penelitian ini sejalan dengan hasil penelitian yang dilakuykan oleh (A.A.Ayu Ngr. Dinni Saraswathi. et al., 2017) menyatakan efikasi diri berpengaruh positif pada pengembangan karir pegawai. Efek moderasi dukungan organisasional terhadap pengembangan karir juga ditemukan signifikan yang artinya dukungan organisasional mampu memoderasi (memperkuat) pengaruh efikasi diri terhadap pengembangan karir pegawai.

\section{Kesimpulan dan Rekomendasi}

\subsection{Kesimpulan}

Dari uraian-uraian sebelumnya, penulis mencoba mengambil beberapa kesimpulan sebagai berikut:

1) Work family conflict (WFC) berpengaruh signifikan terhadap pengembangan karir karyawan pada Badan Pengelola Pajak dan Retribusi Daerah Kota Medan.

2) Efikasi diritidak berpengaruh terhadap pengembangan karir karyawan pada Badan Pengelola Pajak dan Retribusi Daerah Kota Medan.

3) Dukungan organisasi tidak terbukti memoderasi pengaruh work family conflict (WFC) terhadap pengembangan karir karyawan pada Badan Pengelola Pajak dan Retribusi Daerah Kota Medan.

4) Dukungan organisasi terbukti memoderasi pengaruh efikasi diri terhadap pengembangan karir karyawan pada Badan Pengelola Pajak dan Retribusi Daerah Kota Medan.

\subsection{Rekomendasi}

1) Perusahaan memfasilitasi sedini mungkin konflik yang terjadi dengan memberdayakan atasan untuk memberikan konseling atau layanan konseling melalui orang-orang yangprofesional. Hal ini dapat mendeteksi dengan cepat konflik yang terjadi dan mencegahterjadinya hal-hal yang merugikan perusahaan seperti mangkir atau aktivitas yang kontraproduktif. Perusahaan juga perlu memberikan benefit untuk karyawan seperti family gathering, sehingga ada kesempatan untuk rekreasi bersama-sama dengan atasannya pada suatu kesempatan.

2) Pihak manajemen harus memperhatikan tingkat efikasi diri pegawai terutama pada aspek psikologis. Hal ini dikarenakan pegawai yang berstatus honorer memiliki tingkat efikasi diri yang lebih rendah dibandingkan pegawai yang berstatus PNS. Khususnya untuk pegawai yang berstatus honorer yang sudah berumur dalam hal penguasan dan mengoperasikan komputer masih sangat kurang. Sebaikknya pihak manajemen memberikan motivasi untuk membangkitkan tingkat efikasi diri pegawai agar dalam praktek pekerjaan pegawai merasa memiliki kemampuan untuk selalu berhasil melaksanakan pekerjaannya.

3) Dukungan organisasional pada Badan Pengelola Pajak dan Retribusi Daerah Kota Medan masih sangat perlu ditingkatkan mengingat dukungan organisasional memiliki pengaruh yang lebih besar dibandingkan dengan efikasi diri dalam rangka mencapai kinerja yang maksimal. Pegawai lebih membutuhkan faktor dukungan organisasional sebagai motivasi mereka untuk tetap loyal kepada organisasi. Dalam upaya meningkatkan kinerja pegawai, hal ini sangat perlu diperhatikan oleh pihak manajemen Kantor Badan 
Pengelola Pajak dan Retribusi Daerah Kota Medan. Upaya selanjutnya yang dapat dilakukan sebaiknya pihak manajemen lebih memperhatikan aspek dukungan organisasional dalam hal dukungan dari atasan berupa perhatian, pujian, penerimaan, keakraban, informasi dan pengembangan diri. Apabila hal-hal tersebut dapat dilakukan maka pegawai akan merasa bahwa mereka merupakan bagian penting bagi organisasi, sehingga akan tercipta suasana saling mendukung antara pegawai dengan organisasi untuk mencapai tujuan dari organisasi.

\section{Daftar Pustaka}

A.A. Ayu Ngr. Dinni Saraswathi., Dewi, I. G. A. M., \& Piartini, P. S. (2017). Stres Kerja Sebagai Pemoderasi Dalam Work Family Conflict, Fakultas Ekonomi dan Bisnis Universitas Udayana, Bali , Indonesia, 2257-2286.

Afrilia, L. D., \& Utami, H. N. (2018). Pengaruh Work-Family Conflict terhadap Kepuasan Kerja dan Kinerja (Studi pada Karyawan Wanita Rumah Sakit Permata Bunda Malang). Jurnal Administrasi Bisnis, 55(2), 48-56.

Blau, P. M. (2017). Exchange and power in social life. Exchange and Power in Social Life, 1-352. https://doi.org/10.4324/9780203792643

Candra, N., \& Ardana, I. (2016). Pengaruh Pengalaman Kerja, Pendidikan Dan Pelatihan Terhadap Pengembangan Karir Di Pt. Pln (Persero) Distribusi Bali. E-Jurnal Manajemen Universitas Udayana, 5(9), 254863.

Frone, M. R., Russell, M., \& Cooper, M. L. (1992). Antecedents and Outcomes of Work-Family Conflict: Testing a Model of the Work-Family Interface. Journal of Applied Psychology. https://doi.org/10.1037/0021-9010.77.1.65

Greenhaus, J. H., \& Beutell, N. J. (1985). ' Aatdemy of MamD^menl Revieiv Sources of Conflict Between Work and Family Roles^. Academy of Management Review, 10(1), 76-88.

Handoko, T. H. (2011). Manajemen Personalia dan Sumber Daya Manusia. In Pengantar Manajemen.

Jackson, \& Yohanes Arianto. (2017). Jurnal KREATIF : Pemasaran, Sumberdaya Manusia dan Keuangan, Vol. 5, No.1, Oktober 2017. Jurnal KREATIF, 5(1), 18-29.

Jati Waskito, S. Ms., \& Ir. H. Irmawati, S. Ms. (2012). Perbedaan Gender dan Sikap terhadap Peran Pekerjaan-Keluarga: Implikasinya pada Perkembangan Karir Wanita. הנ ו טע עלו ו, 66, 37-39.

Marler, J. H., Fisher, S. L., \& Ke, W. (2009). Employee Self-Service Technology Acceptance: a Comparison of Pre-Implementation and Post-Implementation Relationships. Personnel Psychology, 62(2), 327-358. https://doi.org/10.1111/j.1744-6570.2009.01140.x

Muamarizal, S., Dr. Samsir, SE., M.Si Marzolina, SE, M., \& Faculty. (2015). Pengaruh Pengalaman Kerja Dan Penilaian Prestasi Kerja Terhadap Pengembangan Karir Karyawan pada PT. Jasaraharja Putera Cabang Pekanbaru. Ekp, 13(3), 1576-1580.

Nurtjahjanti, H., Endah Mujiasih, Prihatsanti, U., Prasetyo, A. R., \& Ratnaningsih, I. Z. (2012). Hubungan Antara Efikasi Diri Dan Persepsi Terhadap Pengembangan Karir Dengan Work Family Conflict Pada Polwan Di. ... Promoting Harmony in ....

Rhoades, L., \& Eisenberger, R. (2002). Perceived organizational support: A review of the literature. Journal of Applied Psychology, 87(4), 698-714. https://doi.org/10.1037/00219010.87.4.698

Settoon, R. P., Bennett, N., \& Liden, R. C. (1996). Social exchange in organizations: Perceived organizational support, leader-member exchange, and employee reciprocity. Journal of Applied Psychology, 81(3), 219-227. https://doi.org/10.1037//0021-9010.81.3.219

Sugiyono. (2012). Metode Penelitian Kuantitatif, Kualitatif dan R \& D.Bandung:Alfabeta. Metode Penelitian Kuantitatif, Kualitatif Dan $R \quad \& \quad$ D.Bandung:Alfabeta. https://doi.org/10.1017/CB09781107415324.004 
TARGET : JURNAL MANAJEMEN DAN BISNIS | e-ISSN : 2715-9361 | Vol. 2 No. 2 | Desember 2020 DOI https://doi.org/10.30812/target.v2i2.994

Triaryati, N. (2003). Pengaruh Adaptasi Kebijakan Mengenai Work Family Issue Terhadap Absen

Dan Turnover. Jurnal Manajemen Dan Wirausaha, 5(1), 85-96.

https://doi.org/10.9744/jmk.5.1.pp.85-96 